\title{
Hyaluronic acid production in vitro by synovial lining cells from normal and rheumatoid joints
}

\author{
INGER MARIE S DAHL* AND GUNNAR HUSBY
}

From the Institute of Clinical Medicine, University of Troms $\phi, N-9000$ Troms $\phi$, Norway; and the ${ }^{*}$ Department of Medical and Physiological Chemistry, University of Uppsala, BMC, Box 575, S-751 23 Uppsala, Sweden

SUMMARY Organ cultures and primary cell cultures were established from synovial tissue collected from patients with rheumatoid arthritis. Hyaluronic acid measured by the incorporation of $\left[{ }^{3} \mathrm{H}\right]$ glucosamine into the polysaccharide was found to be synthesised in the cultures immediately after transfer from in-vivo to in-vitro conditions. This was in contrast to the primary cultures established from cells isolated from normal joints. The latter cells did not synthesise any detectable hyaluronate. $90-100 \%$ of the cells in primary culture were found to be esterase positive, indicating their macrophage nature. The molecular weight of the hyaluronate produced by the pathological cells was low $(\sim 50000)$ compared with the molecular weight of hyaluronate found in joint fluid from normal or rheumatoid joints. Cell lines of fibroblasts established from rheumatoid joints and studied after four or seven passages also produced hyaluronate of low molecular weight. It is known that similar cell lines from normal joints produce a high molecular weight polymer.

Key words: biosynthesis, synovial cells, rheumatoid arthritis, in vitro.

Rheumatoid arthritis is characterised among other things by a hypertrophy of the cell layer lining the synovial cavity, an accumulation of polymorphonuclear cells, lymphocytes, plasma cells, and macrophages in the synovial tissue, and an increased volume of synovial fluid and thereby an increased amount of hyaluronic acid (sodium hyaluronate) in the joint.

The synovial lining cells exhibit different forms, which have been designated $A, B$, and $C$ cells. ${ }^{1}$ The $A$ cells show the morphology of macrophages and they are active in phagocytosis; the B cells exhibit an extensive Golgi apparatus, indicating a secreting function, and they have been assumed to produce hyaluronic acid; and the $C$ cells have an intermediate appearance. When the synovial cells have been established as cell lines in vitro they take on a fibroblast-like appearance ${ }^{2}$ even if certain of their previous characteristics can be induced by various compounds. ${ }^{3-5}$

Many authors have grown synovial cells, both normal and rheumatoid, in culture and studied the

Accepted for publication 19 March 1985.

Correspondence to Dr Inger Marie S Dahl, Department of Medicine, University Hospital, N-9000 Tromsø, Norway. production of hyaluronic acid and the effects of drugs on this activity. However, these studies have been performed mainly with well established cultures when the cells exhibit a fibroblast-like appearance (see e.g., references 3, 6-12). It can be argued that the results do not reflect in-vivo hyaluronic acid metabolism. Some studies have, however, been performed on organ cultures where the synovial membrane or villi from this membrane were used. ${ }^{13}$ In the present investigation we have attempted to isolate synovial lining cells from normal and rheumatoid joints and to study their hyaluronate production immediately after transfer to culture when they still possess a morphology resembling that shown in vivo. We have found that the normal lining cells under these conditions do not produce any appreciable amount of hyaluronate, whereas the rheumatoid cells produce the polysaccharide but with an unexpectedly low molecular weight.

\section{Patients and methods}

PAT IENTS

Synovial tissue was obtained during therapeutic synovectomies from 10 women and four men (Table 1) 


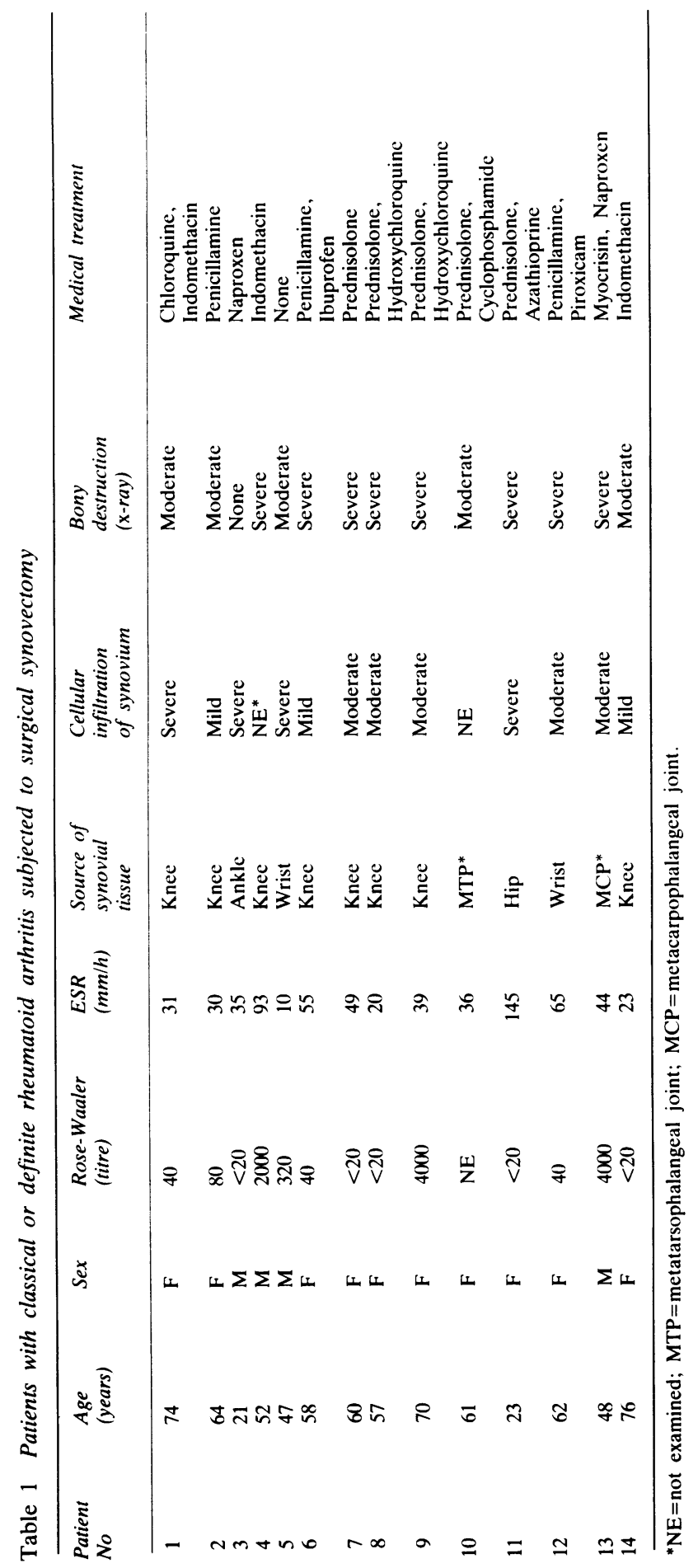


with definite or classical rheumatoid arthritis according to the criteria of the American Rheumatism Association. ${ }^{14}$ Histology of the removed synovium was performed in 12 cases and was consistent with the diagnosis active rheumatoid arthritis.

CELL AND ORGAN CULTURES FROM

RHEUMATOID TISSUE

The specimens of proliferated and inflamed synovium $(50 \times 50 \mathrm{~mm})$ intended for organ cultures were immediately incubated at $37^{\circ} \mathrm{C}$ in $10 \mathrm{ml}$ RPMI medium 1640 (Flow Laboratories, Irvine, Scotland) containing $20 \%$ new-born calf serum (Flow Laboratories) and $12.5 \mathrm{mCi} / \mathrm{l}$ of $\left[{ }^{3} \mathrm{H}\right]$ glucosamine (Amersham International, Amersham, UK) for 10, 15, 60, and $90 \mathrm{~min}$. The incorporation was terminated by addition of a large excess of non-labelled glucosamine and the medium analysed for labelled hyaluronate.

The synovial specimens intended for cell cultures were transferred to RPMI medium prewarmed to $37^{\circ} \mathrm{C}$ and taken to the laboratory within $15 \mathrm{~min}$. Single cell suspensions were prepared as described by Abrahamsen et al. ${ }^{15}$ and Klareskog et al. ${ }^{16}$ The proliferated synovium was carefully dissected under the microscope from fat and fibrous material and cut into small pieces. These were suspended in a balanced salt solution containing $20 \mathrm{mM}$ HEPES $\mathrm{pH}$ $7.4,0.5 \mathrm{~g} / \mathrm{l}$ of collagenase (Worthington, New Jersey, USA), $0 \cdot 15 \mathrm{~g} / \mathrm{l}$ of deoxyribonuclease (Sigma, St Louis, Missouri, USA) and $10 \mathrm{~g} / \mathrm{l}$ of human serum albumin (AB KABI, Stockholm, Sweden). The mixture was stirred carefully (100 rotations per min) on a New Brunswick incubator shaker for about $2 \mathrm{~h}$ at $37^{\circ} \mathrm{C}$. Large pieces remaining in the digest were removed by filtration through a sterile Dacron filter (mesh 80). The resulting single cell suspension was cleared from dead cells and subcellular material by centrifugation at room temperature through a cushion of $22 \%$ Percoll (Pharmacia Fine Chemicals, Uppsala, Sweden) containing $0 \cdot 15 \mathrm{~g} / \mathrm{l}$ of deoxyribonuclease. ${ }^{16}$ In three patients the cells were separated according to density on a Percoll gradient. Fractions with densities of $1.043-1.055 \mathrm{~g} / \mathrm{ml}$ and $1 \cdot 055-1.080 \mathrm{~g} / \mathrm{ml}$ were collected. ${ }^{17}$

After washing with RPMI medium containing $20 \%$ human serum, $50 \mathrm{IU} / \mathrm{ml}$ of penicillin, and 50 $\mathrm{mg} / \mathrm{l}$ of streptomycin the cells were counted in the presence of trypan blue and showed a viability of more than $95 \%$. The cells were seeded on Petri dishes (diameter $60 \mathrm{~mm}$, Costar, Cambridge, Massachusetts, USA) in the same medium in an amount of $1.5 \times 10^{6}$ cells in $5 \mathrm{ml}$. To this was added $\left[{ }^{3} \mathrm{H}\right]$ glucosamine $(10 \mathrm{mCi} / \mathrm{l})$. After incubation for 30 min to $48 \mathrm{~h}$ at $37^{\circ} \mathrm{C}$ in $5 \% \mathrm{CO}_{2}$ the cultures were washed free of non-adherent cells, and the medium was analysed for labelled hyaluronate. The adherent cells (about $40-80 \%$ of the original cells in suspension: $20000-30000 \mathrm{cells} / \mathrm{cm}^{2}$ ) were incubated with fresh medium containing the same additions as above, including $\left[{ }^{3} \mathrm{H}\right]$ glucosamine, and grown for 15 to $84 \mathrm{~h}$. Aphidicolin (kindly donated by Dr Hans Krokan, Troms $\emptyset$ ) at a concentration of $4 \mathrm{mg} / \mathrm{l}$ was added in three cases to prevent cell division. ${ }^{18}$ After termination the medium was analysed for labelled hyaluronate. In some experiments the above cell cultures were treated with $0.05 \%$ trypsin for $3 \mathrm{~min}$ to remove possible fibroblasts (very few). After addition of fresh medium and serum the subsequent synthesis of hyaluronic acid was recorded.

CULTURES OF NORMAL SYNOVIAL LINING CELLS

Lining cells were isolated within 15-120 minutes after death from three persons aged 63,71 , and 83 years respectively, who had died in heart infarction. They had no history of joint disease or postmortem signs of joint affections. The procedure described by Fraser and McCall was employed. ${ }^{2}$ Briefly, the knee joints were rinsed twice with medium warmed to $37^{\circ} \mathrm{C}$ through a needle inserted beneath the patella. Then a balanced salt solution containing $0.25 \%$ trypsin (SBL, Stockholm, Sweden) was deposited in the joint. After 5 to 10 min of gentle massage the cell/trypsin mixture was withdrawn, serum was added to inactivate the trypsin, and the cells were filtered through a Dacron filter and collected by centrifugation at $400 \mathrm{~g}$ for $5 \mathrm{~min}$. The cells were resuspended in RPMI medium containing $10 \mathrm{mCi} / 1$ of $\left[{ }^{3} \mathrm{H}\right]$ glucosamine and $20 \%$ fetal calf serum or human serum. The cells were cultured as described above for rheumatoid cells. The trypan blue exclusion test showed a viability of between 95 and $98 \%$.

The cells prepared by this technique have been well characterised ${ }^{19}$ and represent a subpopulation of normal synovial lining cells. A large majority are esterase positive, carry $\mathrm{Fc}$ receptors, and express HLA-DR antigens like the cells obtained from rheumatoid joints. In our experiments both isolated cells from rheumatoid tissue and normal synovial lining cells were examined for non-esterase activity by the method of Yam. ${ }^{20}$ All the cell preparations appeared to contain $90-100 \%$ esterase positive cells.

SYNOVIAL FIBROBLAST CULTURES

In five cases fibroblast-like cells were allowed to grow out from pieces of rheumatoid synovial membranes. During 14 days a dense monolayer was formed. The cells were then released by trypsinisation, ${ }^{21}$ carried through four passages, and finally grown in Dulbecco's medium (Flow Laboratories) containing $20 \%$ human serum at a mean 
density of 40000 cells $/ \mathrm{cm}^{2}$. The cells were grown in plastic flasks (Costar) without coating or coated with collagen $^{22}$ or fibronectin. ${ }^{23}$ In one flask without coating human serum was exchanged for human fetal serum. In two cases the cells were investigated after seven passages in medium containing $20 \%$ human serum or human fetal serum. The mean cell densities obtained were 250000 cells $/ \mathrm{cm}^{2}$.

ISOLATION OF HYALURONATE

Hyaluronate was isolated from the culture medium. Only a minor part of the radioactivity incorporated into high molecular weight material was detected in the cellular fraction $(20 \%)$. The media were made $6.5 \mathrm{M}$ in urea and $0.05 \mathrm{M}$ in trometamol (TRIS)$\mathrm{HCl}$ buffer $\mathrm{pH} 6.5$ and chromatographed on diethylaminoethyl (DEAE)-cellulose as described by Dahl and Cöster. ${ }^{24}$ After application of the samples the columns were eluted stepwise with $(a)$ urea/ TRIS buffer; (b) urea/TRIS+0.15 M NaCl; (c) urea/TRIS + $0.5 \mathrm{M} \mathrm{NaCl}$; and $(d)$ urea/TRIS + $2 \mathrm{M}$ $\mathrm{NaCl}$. The hyaluronate was eluted entirely in the 0.5 $\mathrm{M} \mathrm{NaCl}$ fraction as shown with high molecular weight standard samples of labelled hyaluronate (kindly supplied by Dr J R E Fraser). The recovery was $70-90 \%$. This fraction was dialysed against distilled water and lyophilised.

CHARACTERISATION OF THE HYALURONATE The molecular weight distribution of the hyaluronate was determined quantitatively by chromatography on the column of mixed agarose gels described by Laurent and Granath ${ }^{25}$ or qualitatively by chromatography on Sephacryl S-300 and S-1000 (Pharmacia Fine Chemicals). The chromatographic details are given in the legends to the figures. To confirm the lable was incorporated into hyaluronate, the samples were dissolved in $0.1 \mathrm{M}$ TRIS- $\mathrm{HCl}$ buffer $\mathrm{pH} \mathrm{7.0}$ and incubated with hyaluronidase from Streptomyces hyalurolyticus $\left(10 \mathrm{U} / \mathrm{ml}, 50^{\circ} \mathrm{C}, 12\right.$ h, Seikagaku Kogyo, Ltd, Tokyo, Japan) and rechromatographed on Sephacryl columns.

TESTS FOR HYALURONIC ACID DEGRADING A CTIVITY

Experiments were performed to check for possible hyaluronic acid degrading activity in the cultures of rheumatoid cells, in three serum batches used in cell culturing, and finally in serum and synovial fluid from patients with rheumatoid arthritis. Determination in serum was made by incubating $1 \mathrm{ml}$ of serum, $4 \mathrm{ml}$ of medium, and $10 \mu \mathrm{g}$ of high molecular weight hyaluronate (Healon) for $48 \mathrm{~h}$ at $37^{\circ} \mathrm{C}$. The mixture was then chromatographed on Sephacryl S-1000 and the eluate analysed by a sensitive assay for hyaluronic acid. ${ }^{26}$ Experiments on cell cultures were performed with a ${ }^{3} \mathrm{H}$-labelled hyaluronic acid of molecular weight $6 \times 10^{5}$ (gift from Dr J R E Fraser), which was added to cultures of rheumatoid. cells or rheumatoid tissues in amounts of $240 \mathrm{ng}$ pe $5 \mathrm{ml}$ flask. After incubation for $48 \mathrm{~h}$ at $37^{\circ} \mathrm{C}$ the medium was chromatographed as above and the eluate analysed for radioactivity. Similar experics ments were performed on synovial fluid fron $\bar{g}$ rheumatoid patients, but in these experiments a $\left[{ }^{3} \mathrm{H}\right]$ hyaluronate of molecular weight 300000 was added in amounts of $240 \mathrm{ng}$ to 0.2 or $2 \mathrm{ml}$ fluidO Chromatography on Sephacryl S-1000 was also used to show that DEAE chromatography did not dee grade high molecular weight radioactive hyalur onate.

\section{Results}

CELL CHARACTERISATION

Cells isolated from normal joints by trypsin treat $-\stackrel{+}{-}$ ment or cells isolated from rheumatoid synoviab tissues by collagenase digestion were allowed to adhere to plastic dishes. At the light microscopic level both preparations showed similar characteris $\overrightarrow{0}$ tics, i.e., they showed a heterogeneous cell popula@ tion with small rounded cells, non-dendritic macrophage-like cells, and dendritic cells often wathloo swelling in the end of the extensions. A very fibroblast-like, elongated cells were seen, and of few cells could be removed from the plastic dishes by trypsin treatment. In some experiments the cells were examined for non-esterase activity and the appeared to be highly esterase positive. Furthep characterisation of similar cell preparations has bee $\overrightarrow{5}$ published by other authors. ${ }^{19}$ 27-29 Cell lines estab 3 lished from rheumatoid synovial cells were studied after four and seven passages. At this stage the cells? had the general appearance of fibroblasts.

IDENTIFICATION AND PRODUCTION OF

HYALURONATE IN SYNOVIAL CELLS The $0.5 \mathrm{M} \mathrm{NaCl}$ fraction from DEAE-cellulose which should contain the hyaluronic acid in the medium, was isolated as described. In order to confirm that the radioactivity of this fraction hao been incorporated into hyaluronic acid the materiaE. was chromatographed on Sephacryl S-300 or S-1000 before and after treatment with hyaluronidase from Streptomyces hyalurolyticus. The main part of the radioctive material in this fraction produced by rheumatoid cells was susceptible to the enzyme (Figse $1 \mathrm{~A}$ and 1B). There was, however, some material iff the void fraction and a distinct peak in the middle of the chromatogram that were unaffected by hyalur ${ }^{+}$ onidase. The results in Table 2 concerning the primary cell cultures give both the total incorpora稌 tion of radioactivity into the $0.5 \mathrm{M} \mathrm{NaCl}$ fraction? 


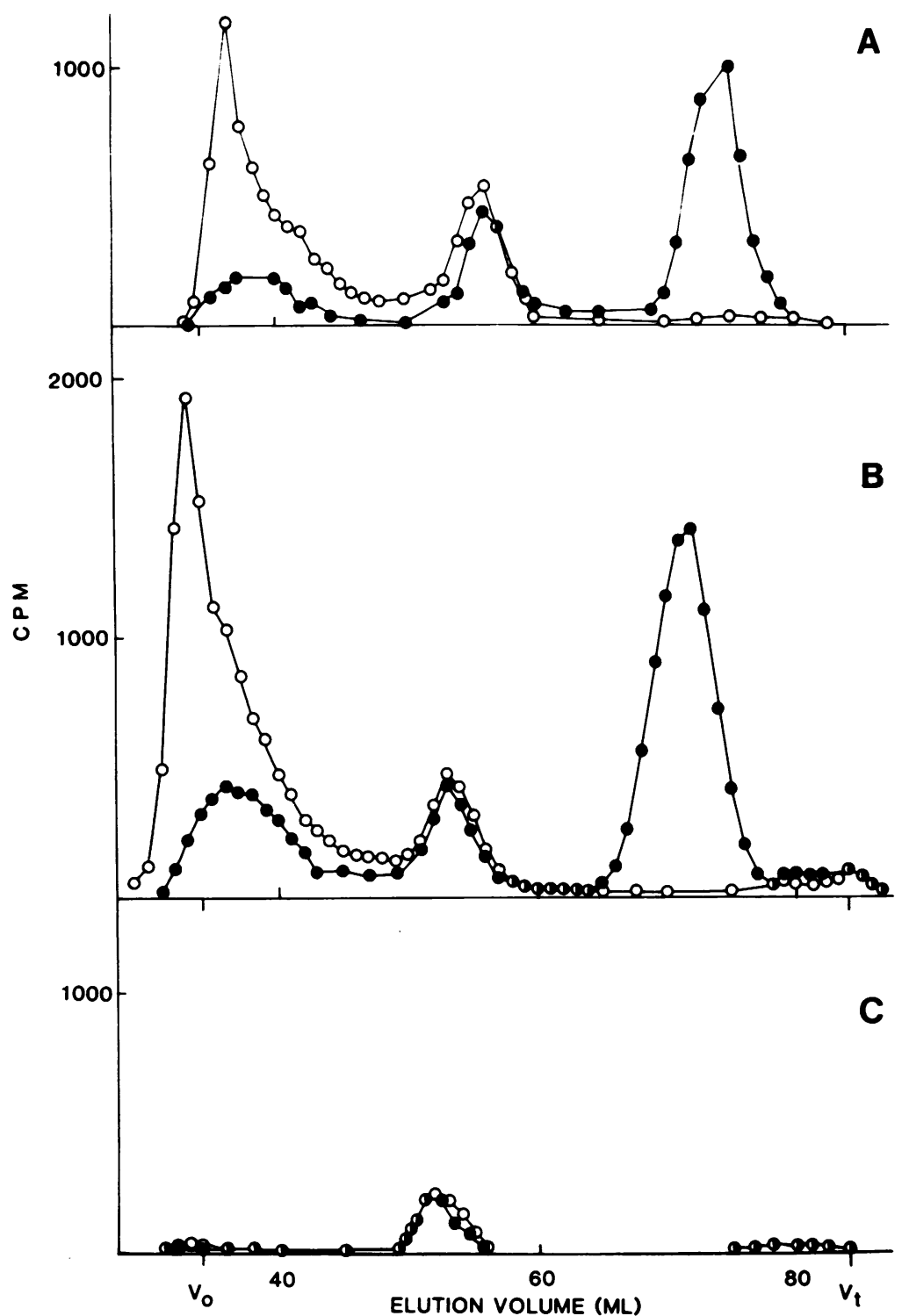

Fig. 1 Experiments to identify hyaluronic acid in the medium from primary cultures of $(A)$ rheumatoid synovial organ culture, $(B)$ cell culture from rheumatoid synovium, and $(C)$ normal synovial lining cells. $(A)$ Specimens of proliferated and inflamed synovium were immediately incubated in medium containing $\left[{ }^{3} \mathrm{H}\right]$ glucosamine for $90 \mathrm{~min}$. The culture medium was chromatographed on DEAE-cellulose, the $0.5 \mathrm{M} \mathrm{NaCl}$ fraction was recovered and an aliquot applied to a $1.05 \times 104$ cm column of Sephacryl S-300 at room temperature. The column was eluted with phosphate-buffered saline pH 7.25, containing $0.02 \%$ sodium azide, at a flow rate of $10 \mathrm{ml} / \mathrm{h}$, and $1 \mathrm{ml}$ fractions were collected $\left(\mathrm{O}^{-} \mathrm{O}\right)$. An equal amount of material digested with hyaluronidase as described in 'Methods' was chromatographed in a subsequent run (- -

Approximately $64 \%$ of the total radioactivity moved from the void volume to the total volume by the enzyme treatment. Some material in the void volume $(17 \%)$ and a distinct peak in the middle of the chromatogram (19\%) were not attacked by the enzyme. (B) Cells were established from patient No 4 and grown in $\left.I^{3} \mathrm{H}\right]$ glucosamine. The medium collected between 5 and $27 \mathrm{~h}$ of culture was chromatographed on DEAE-cellulose and the $0.5 \mathrm{M} \mathrm{NaCl} \mathrm{fraction} \mathrm{recovered.} \mathrm{An} \mathrm{amount} \mathrm{of}$ radioactivity, corresponding to the incorporation by $10^{\circ}$ cells during one hour, was chromatographed on Sephacryl S-300 before $\left(\mathrm{O}^{-} \mathrm{O}\right)$ and after $\left(\mathrm{O}^{-}\right.$) hyaluronidase treatment. Approximately $61 \%$ of the total radioactivity was degraded; $15 \%$ in the middle of the chromatogram and $24 \%$ in the void volume were not attacked by the enzyme. (C) Cells were established

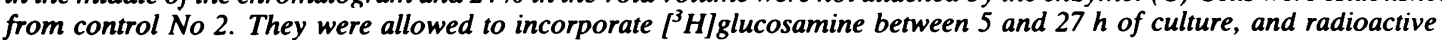
material was collected and processed as above. Only trace amounts of hyaluronate could be identified, while the material in the middle of the chromatogram appeared in amounts similar to those in the rheumatoid cells. 


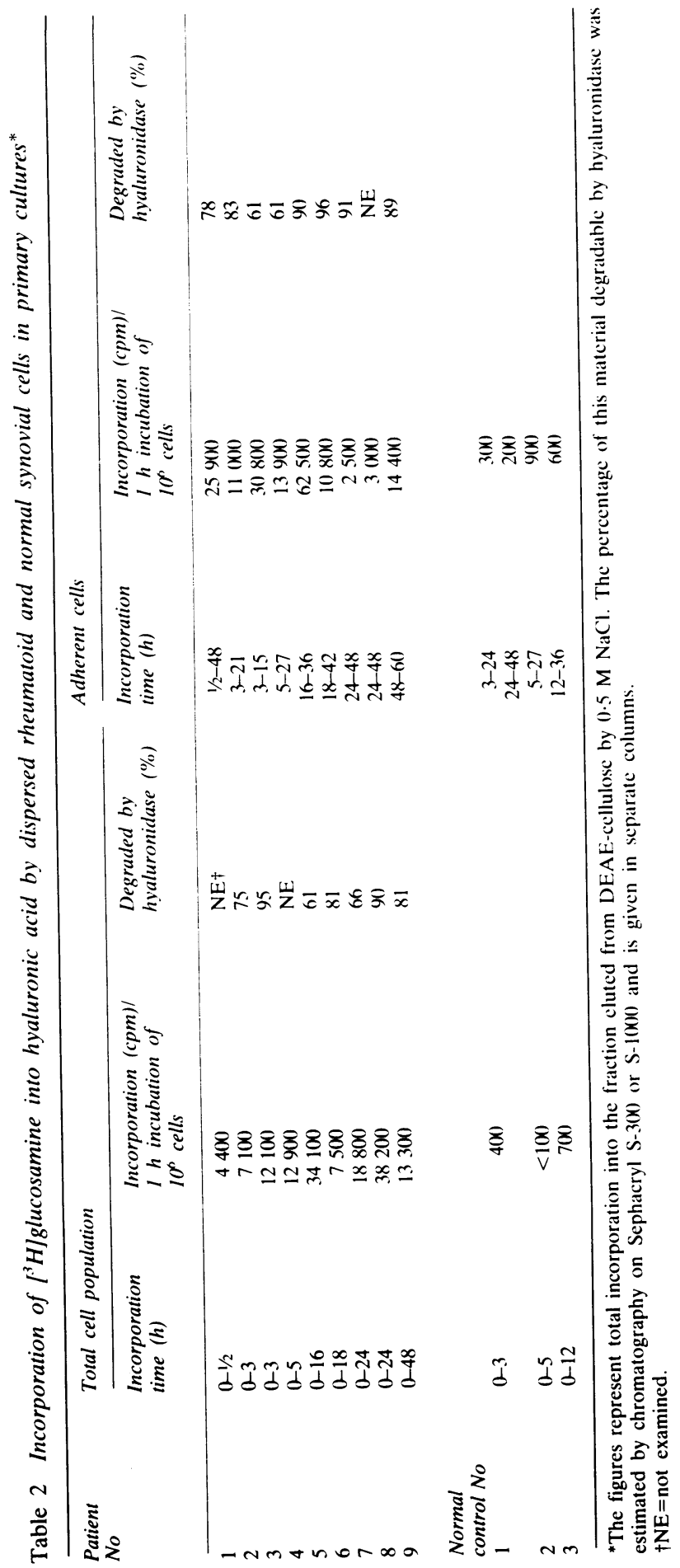


and the percentage of this material susceptible to hyaluronidase. Some chromatograms did not show sufficient resolution to distinguish completely between undegraded and degraded hyaluronate, and in these instances the figures give the minimum amount of degradable material.

Pieces of synovial membrane (from patients 4 and 10 in Table 1) were incubated for 15 to 90 min with $\left[{ }^{3} \mathrm{H}\right]$ glucosamine. Hyaluronate production was not observed until $90 \mathrm{~min}$, indicating a lag time between the addition of precursor and the appearance of the final product. The incorporation at $90 \mathrm{~min}(40000$ cpm of hyaluronidase-susceptible material per culture) was not analysed in terms of cell number in the synovial tissue and is thus only a qualitative indication for hyaluronate production in the intact organ (Fig. 1A).

Cells dispersed from rheumatoid synovium were incubated for varying times in plastic dishes, and the incorporation of isotope into hyaluronate was measured when the total cell population was present. Non-adherent cells were then removed by washing and the hyaluronate synthesis measured in the adherent cells only (Table 2). There was a significant but highly variable hyaluronate production both before and after the non-adherent cells had been removed. The accumulation of hyaluronate in the medium was observed already during the first half hour of culture and continued throughout the period of observation (up to $60 \mathrm{~h}$ ). There was no apparent difference in the synthesis of hyaluronate in the total cell population compared with the adherent cells.

In two experiments rheumatoid cells were separated by Percoll centrifugation into a high density and a low density fraction. ${ }^{17}$ There was no clear difference in hyaluronate production between the two cell populations (data not shown).

The normal synovial lining cells behaved very differently from the rheumatoid cells. Only trace amounts of hyaluronate were produced in the cultures (Fig. 1C, Table 2). There was, however, an incorporation into the unknown compound, which appears in the middle of the Sephacryl S-300 chromatogram (Fig. 1C).

Fibroblast-like cell lines were established from some of the patients and their hyaluronate production was studied after four and seven passages. The production of hyaluronate by these cells is shown in Table 3 . On average these cells seem to synthesise less than the cells in primary cultures (Table 2), though the results are somewhat variable. The production seems to be independent of the substrate on which the cells grow (plastic, fibronectin, collagen) or the serum added to the medium (human serum, human fetal serum).

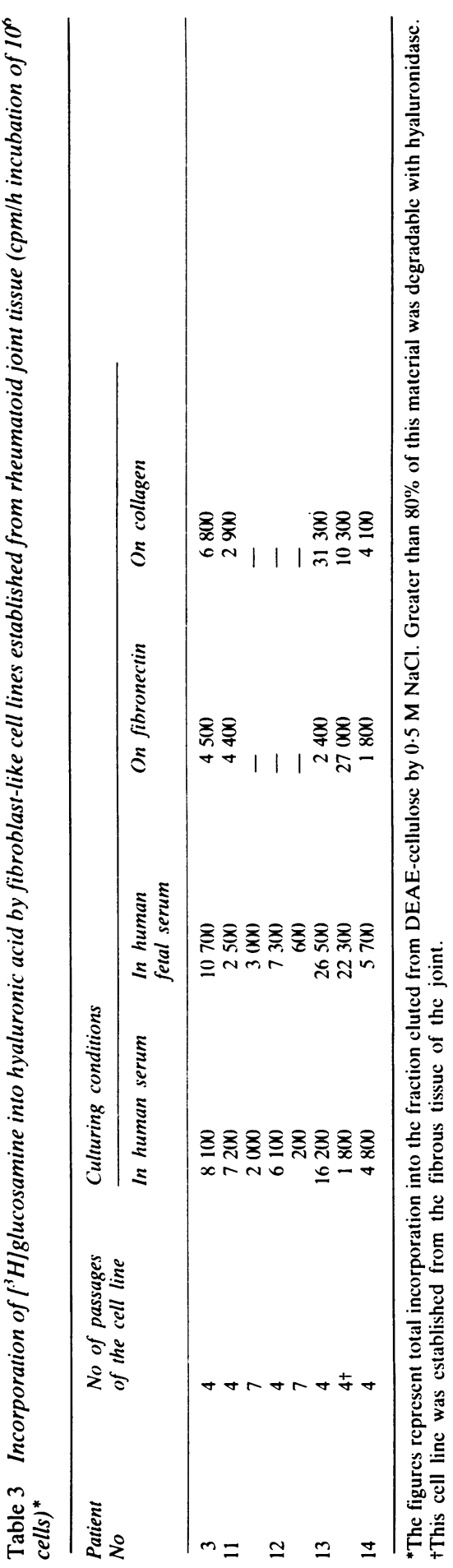



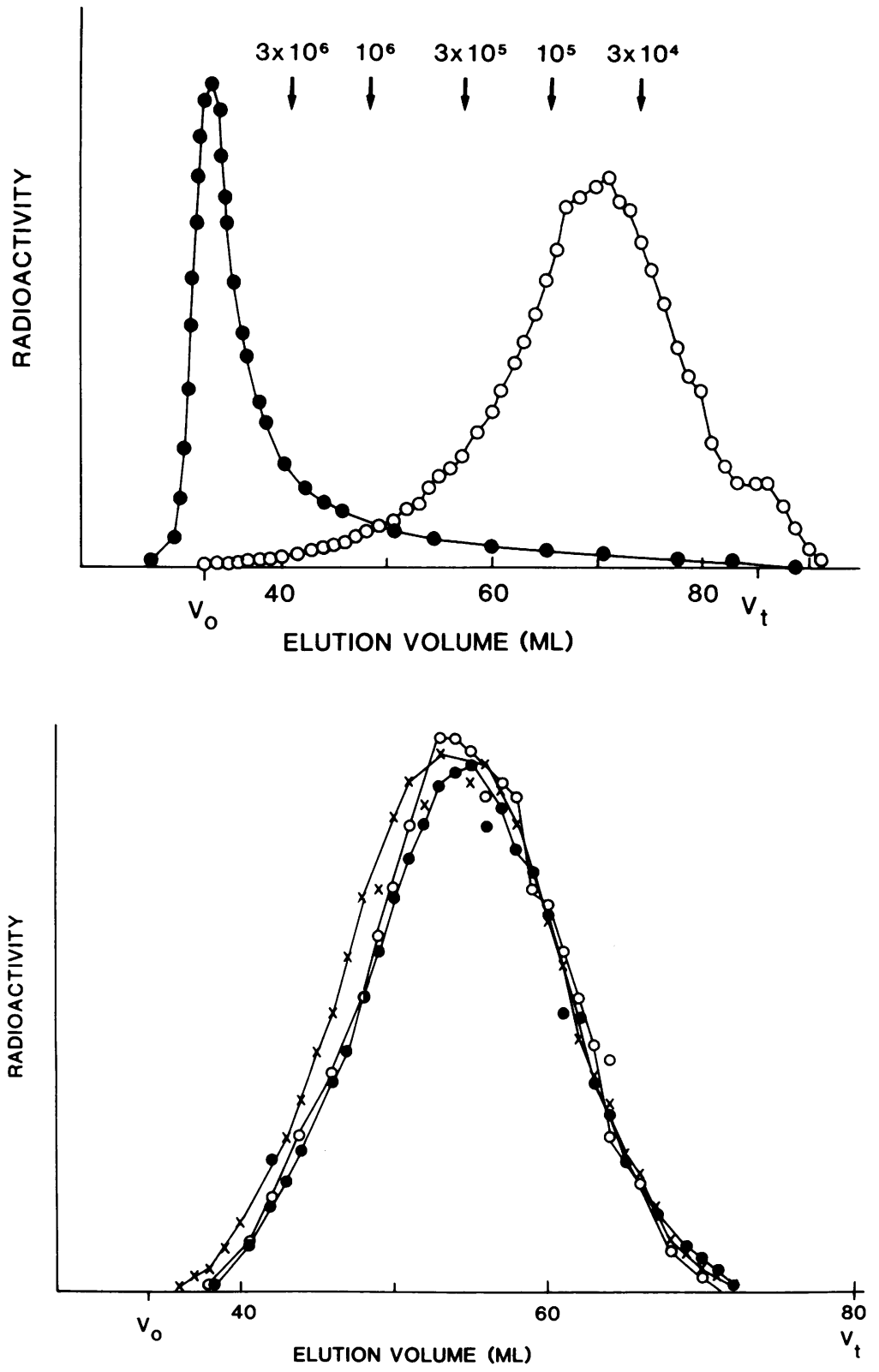

Fig. 2 Chromatography of $\left.{ }^{3} \mathrm{H}\right]$ hyaluronic acids on a mixed $\overrightarrow{\vec{z}}$ bed of $0.5 \% 14 \%$ agarose. The product synthesised by an established fibroblast-like cell line $\underline{\square}$ from normal synovial cells $(-1) \overline{0}$ (gift from $\operatorname{Dr} J R$ A Fraser) was $\mathbb{Q}$ compared with hyaluronate synthesised in a primary culture by rheumatoid synovial cells $(\mathrm{O}-\mathrm{O}) . \vec{\circ}$ For chromatographic conditions and calibration of the column seew the paper by Laurent and Granath. $^{25}$ The sites of elution of appropriate calibration fractions. are indicated at the top of the figure. The average molecular weight of the 'normal' cell productio is $>3 \times 10^{6}$ and of the 'pathological' product about $5 \times 10^{4}$.

Fig. 3 Test for hyaluronate degrading activity in cultures rheumatoid cells or rheumatot tissue. ${ }^{3} \mathrm{H}$-Labelled hyaluronate $\vec{\overrightarrow{ }}$ with an average molecular weighto of $6 \times 10^{5}$ was chromatographed on a column of Sephacryl S-1000\% before $(x-x)$ and after incubation for $48 \mathrm{~h}$ at $37^{\circ} \mathrm{C}$ in $a^{\circ}$ primary culture of rheumatoid cells (-) or rheumatoid tissue (O-O). There was no significan? difference in the elution patterns and thus no detectable degradation? of the hyaluronate in the cultures. The chromatographic conditions were: room temperature; column $\delta$ size: $1.05 \times 94 \mathrm{~cm}$; solvent: $0.5 \mathrm{M}$ sodium acetate $p H 7.0+0.02 \%$ 응 sodium azide; flow rate: $10 \mathrm{ml} / \mathrm{h} ;$ fraction volume $1-2 \mathrm{ml}$.
MOLECULAR WEIGHT OF HYALURONATE The radioactive hyaluronates produced in organ and cell cultures were all chromatographed on a column of Sephacryl S-1000 and were all of remarkably low molecular weight and with similar elution volumes. To determine the exact molecular weight a sample from a rheumatoid cell culture (Patient No 4) was chromatographed as described by Laurent an $\Phi$ Granath $^{25}$ on a mixed agarose bed (Fig. 2). The peak eluted in the chromatogram as a calibration fraction of molecular weight $\sim 50000$. The elution ${ }^{+}$ of a sample of hyaluronate synthesised by añ established cell line from normal synovial cells i shown for comparison. 
SEARCH FOR HYALURONATE DEGRADING ACTIVITY IN RHEUMATOID FLUIDS

In view of the low molecular weight of hyaluronate produced by the rheumatoid cells experiments were performed to test whether there was any hyaluronate degrading activity present in the systems. Thus synovial fluid and blood serum from rheumatoid patients were incubated either with small amounts of unlabelled hyaluronate or ${ }^{3} \mathrm{H}$-labelled polysaccharide, and the molecular weight of the polymer was assayed before and after incubation by chromatography on Sephacryl S-1000, without any noticeable change in elution pattern. Similarly, small amounts of radioactive hyaluronate were added to primary cell cultures or organ cultures or rheumatoid synovium and incubated for $48 \mathrm{~h}$ at $37^{\circ} \mathrm{C}$. No degradation of the radioactive polymer was recorded (Fig. 3).

\section{Discussion}

After rheumatoid synovial tissue has been dissected free from underlying connective tissue matrix it can be treated with enzymes to disperse the cells. When cultured, the majority of the cells adhering to the substrate can be divided into two main populations: first, small cells related to the mononuclear phagocytes and secondly, larger cells with a stellate morphology, which have been shown to produce large amounts of prostaglandin $E_{2}$ and collagenase. ${ }^{30}$ Both groups of adherent cells appear to express HLA-DR antigens. ${ }^{16}$

The aim of the present study was to study the production of hyaluronate in primary cultures of rheumatoid synovial cells, when they still retain the above described morphology, since this, to our knowledge, has not been done before. When cell lines are established from the cultures the cells become fibroblast like, and several authors have shown that at this stage they are producers of hyaluronate. 36-12

The synovial and subsynovial layers were carefully dissected from the underlying connective tissue and exposed to collagenase for only a short period to avoid contamination with fibroblasts. In addition, aphidicolin, known to inhibit cell division, ${ }^{18}$ was added to some of the cultures to prevent multiplication of the fibroblasts. From a morphological standpoint less than $5 \%$ of the cells had a fibroblastlike appearance $24 \mathrm{~h}$ after the cells had adhered. In addition, more than $90 \%$ of the total cell population were esterase positive.

After transfer to in-vitro conditions the rheumatoid synovial cells were shown to produce hyaluronate immediately in amounts equal to or larger than those produced by fibroblast cell lines established from rheumatoid joints (compare Tables 2 and 3). A pronounced variability in the synthetic rate was observed in cells from different RA patients.

In contrast to the rheumatoid cells, synovial lining cells from normal controls were not found to produce significant amounts of hyaluronate either in cell suspension or when adhered to substrate. The normal cells were obtained by intra-articular administration of trypsin. The use of a different procedure for isolation of the cells was an experimental necessity in work with human material but opens the possibility that different cell populations have been collected from the normal and pathological joints despite a similar morphology when adhered to substrate. It is unlikely that trypsin treatment of the normal cells explains the lack of hyaluronate production, since addition of similar amounts of trypsin did not affect the synthesis in adherent rheumatoid synovial cells. Hyaluronate production has also been shown in numerous cell lines established by the standard method in tissue culture of cells released with trypsin. The appearance of the unknown peak in the middle of the Sephacryl S-300 chromatogram (Fig. 1) shows that normal and rheumatoid cells have additional similarities in their biosynthetic machinery. It could also be argued that the use of collagenase in the dispersion of rheumatoid synovial cells had stimulated synthesis of hyaluronate, though this is unlikely in view of the apparent hyaluronate production in intact organ cultures of rheumatoid synovial tissue. If these objections are borne in mind the most probable explanation of our results is a pronounced increase in hyaluronate synthesis by the synovial cells in rheumatoid arthritis compared with the normal state. The high production could be a source of the increased total amounts of hyaluronate which are found in inflamed joints.

We were suprised by the observation that the rheumatoid synovial cells and short term organ cultures produced hyaluronate of molecular weight of about 50000 . Vuorio and coworkers ${ }^{10} 31$ have previously reported on the synthesis of underdepolymerised hyaluronate by rheumatoid cells as judged chromatographically, but all previous work on the molecular weight of hyaluronic acid in joint fluid has indicated that even if there is a lower degree of polymerisation the molecular weight is still of the order of $10^{6}$ in rheumatoid joints. ${ }^{32} \mathrm{~A}$ recent study on the molecular weight dispersion of hyaluronate from synovial fluid in rheumatoid patients has confirmed that there is no appreciable amount of low molecular weight polymer (Engström-Laurent, Dahl, Dahl, and Granath, unpublished). This raises the question whether the low 
molecular weight material is a product of the in vitro conditions.

The hyaluronate in rheumatoid cell cultures could be synthesised in a low molecular weight form but could also be produced by degradation of high molecular weight material. No degradation was detected when hyaluronate was added in trace amounts to the cell or organ cultures from rheumatoid tissue or to serum or joint fluid from rheumatoid patients. This does not exclude the possibility of local degradation at the site of synthesis, e.g., before secretion from the cells. It is known that phagocytic cells produce oxygen-derived free radicals, ${ }^{33}$ and that these radicals depolymerise hyaluronic acid. ${ }^{34}$ The radicals have a short lifetime, and their effect should therefore be localised to the neighbourhood of the cell. Free radical formation is therefore a possible explanation for our observation of low molecular hyaluronate. Furthermore, the high oxygen tension in vitro compared with in vivo would promote free radical formation in the cell cultures.

An alternative explanation for the lack of low molecular hyaluronate in synovial fluid could be a rapid disappearance of this material by diffusion through the synovial membranes. It is interesting to note that rheumatoid patients have increased levels of hyaluronate in the general circulation and that this presumably originates from the connective tissues and is due to an increased rate of biosynthesis. ${ }^{35}$ It is not yet known whether the hyaluronate circulating in serum of rheumatoid patients is of low molecular weight.

The authors are deeply indebted to Professor T C Laurent for valuable discussions and help with the manuscript. We greatly appreciate the help from Dr J R E Fraser for providing radioactively labelled hyaluronate and for assistance by isolation of normal synovial cells. We also wish to thank the orthopaedic departments at Troms $\emptyset$ and Uppsala University Hospitals for providing synovial tissues and Ms Hedvig Krane and Ms Liv Melvær for expert technical assistance. The work was supported by a grant from the Swedish Medical Research Council (13X-4), and from the Norwegian Research Council for Science and the Humanities.

\section{References}

1 Barland P, Novikoff A B, Hamerman D. Electronmicroscopy of the human synovial membrane. J Cell Biol 1962; 14: 207-20.

2 Fraser J R E, McCall J F. Culture of synovial cells in vitro. Notes on isolation and propagation. Ann Rheum Dis 1965; 24: 351-9.

3 Fraser J R E, Clarris B J, Baxter E. Patterns of induced variation in the morphology, hyaluronic acid secretion, and lysosomal enzyme activity of cultured human synovial cells. Ann Rheum Dis 1979; 38: 287-94.

4 Baker D G, Dayer J M, Roelke M, Schumacher H R, Krane S M. Rheumatoid synovial cell morphologic changes induced by a mononuclear cell factor in culture. Arthritis Rheum 1983; 26: 8-14.
5 Clarris B J, Baxter E, Michelangeli V P. Activation of huma synovial cells by cholera enterotoxin: correlation of morphole gical responses with adenylate cyclase activities. and the reversing effects of hyaluronidase. Connect Tissue Res 1982: 10. 173-86.

6 Anastassiades T P, Ley J, Wood A. Glycosaminoglycad synthesis and glucose uptake by rheumatoid and nonrheum toid fibroblastic cells in culture. The effect of nutritional factors. Arthritis Rheum 1979: 22: 871-6.

7 Castor C W. Abnormalities of connective tissue cells cultura from patients with rheumatoid arthritis. II. Defective regula tion of hyaluronate and collagen formation. J Lab Clin Med 1971; 77: 65-75.

8 Mohr W, Beneke G. Synovial cell cultures for the study of the pathogenesis of rheumatoid arthritis. Beitr Pathol 1974; 153: 225-43.

9 Saarni H, Tammi M, Vuorio E, Penttinen R. Distribution glycosaminoglycans in rheumatoid cultures and effects cortisol on it. Scand J Rheumatol 1980; 9: 11-6.

10 Vuorio E, Einola S. Hakkarainen S, Penttinen R. Synthesis of underpolymerised hyaluronic acid by fibroblasts cultured fro $\overrightarrow{\mathbb{B}}$ rheumatoid and non-rheumatoid synovitis. Rheumatol Int 1983 2: $97-102$

11 Hamerman D, Smith C. Keiser H D, Craig R. Glycosaminogly cans produced by human synovial cell cultures. Collagen Rela Res 1982; 2: 313-29.

12 Yaron M, Yaron I, Smetana O, Eylan E, Herzberg MD Hyaluronic acid produced by human synovial fibroblasts. Effe \& of polyinosinic-polycytidylic acid (poly I:C) and interferom Arthritis Rheum 1976; 19: 1315-20.

13 Myers S L, Christine T A. Hyaluronate synthesis by synovial villi in organ culture. Arthritis Rheum 1983; 26: 764-70尺

14 Ropes M W, Bennett G A, Cobo S, Jacox R, Jessar R A. revision of diagnostic criteria for rheumatoid arthritis. Fith Rheum Dis 1958; 9: 175-6.

15 Abrahamsen T G, Johnson P M, Natvig J B. Membran characteristics of adherent cells dissociated from rheumato: synovial tissue. Clin Exp Immunol 1977; 28: 474-83.

16 Klareskog L, Forsum U, Malmnäs-Tjernlund U, Kabelitz L Wigren A, Appearance of anti-HLA-DR-reactive cells $\mathrm{m}$ normal and rheumatoid synovial tissue. Scand J Immunol $198 \overrightarrow{\vec{b}}$ 14: $183-92$.

17 Pertoft $\mathrm{H}$, Laurent T C. Sedimentation of cells in colloidal silict (Percoll). In: Patlow T G, Patlow T P, eds. Cell separation methods and selected applications. New York: Academic Press 1982; 1: 115-52.

18 Ikegami S, Taguchi T, Ohashi M, Oguro M, Nagano H, Man⿳亠㐅冋 Y. Aphidicolin prevents mitotic cell division by interfering wi the activity of DNA polymerase- $\alpha$. Nature $1978 ; 275$ : $458-6 \%$

19 Klareskog L, Forsum U, Kabelitz D, et al. Immune functioñ of human synovial cells. Phenotypic and $T$ cell regulato properties of macrophage-like cells that express HLA-DK. Arthritis Rheum 1982; 25: 488-501.

20 Yam L T, Li C Y, Crosby W H. Cytochemical identification of monocytes and granulocytes. Am J Clin Pathol 1971; 55 283-90.

21 Dahl I M S, Johnsen W, Anseth A, Prydz H. The synthesis glycosaminoglycans by corneal stroma cells in culture. Exp Cell Res 1974; 88: 193-7.

22 Rubin K, Oldberg $\AA$, Höök M, Öbrink B. Adhesion of ră hepatocytes to collagen. Exp Cell Res 1978; 177: 165-77.

23 Rubin K, Johansson S, Pettersson I, Ocklind C, Obrink Höök M. Attachment of rat hepatocytes to collagen and fibronectin: a study using antibodies directed against cef surface components. Biochem Biophys Res Commun 1979; 919 86-94.

24 Dahl I M S, Cöster L. Proteoglycan biosynthesis in cultures of corneas and corneal stroma cells from adult rabbits. Exp E\& Res 1978; 27: 175-90.

25 Laurent U B G, Granath K A. The molecular weight 
hyaluronate in the aqueous humour and vitreous body of rabbit and cattle eyes. Exp Eye Res 1983; 36: 481-92.

26 Laurent U B G. Tengblad A. Determination of hyaluronate in biological samples by a specific radioassay technique. Anal Biochem 1980; 109: 386-94.

27 Klareskog L, Forsum U, Wigzell H. Murine synovial intima contains I-A-I-E/C-positive bone-marrow derived cells. Scand J Immunol 1982: 15: 509-14.

28 Janossy G, Panai G. Duke O, Bofill M. Poulter L W, Goldstein G. Rheumatoid arthritis: a disease of $T$ lymphocyte/ macrophage immunoregulation. Lancet 1981: ii: 839.

29 Winchester R J, Burmester G R. Demonstration of Ia antigens on certain dendritic cells and on novel elongate cells found in human synovial tissues. Scand J Immunol 1981; 14: 441-7.

30 Dayer J M, Krane S M, Russell R G G, Robinson D R. Production of collagenase and prostaglandins by isolated adherent rheumatoid synovial cells. Proc Natl Acad Sci USA 1976; 73: 945-9.
31 Vuorio E. Takala I, Pulkki K. Einola S. Effects of sodium aurothiomalate on hyaluronic acid synthesis in normal and rheumatoid synovial fibroblast cultures. Scand $J$ Rheumatol 1979; 8: 173-6.

32 Sundblad L. Glycosaminoglycans and glycoproteins in synovial fluid. In: Balazs E, Jeanloz R W, eds. The amino sugars. New York, London: Academic Press, 1965; Ila: 29-50.

33 Fantone J C. Ward P A. Role of oxygen-derived free radicals and metabolites in leucocyte-dependent inflammatory reactions (review article). Am J Pathol 1982; 107: 397-418.

34 DelMaestro $R$ F, Arfors $K$ E, Lindblom $R$. Free radical depolymerization of hyaluronic acid: influence of scavenger substances. Bibl Anat 1978; 18 (suppl): 132-5.

35 Engström Laurent A, Hällgren R. Circulating hyaluronate in rheumatoid arthritis: relationship to inflammatory activity and the effect of corticosteroid therapy. Ann Rheum Dis 1985; 44: 83-8.

\section{Book reviews}

Clinical Application of Monoclonal Antibodies. Ed. E S Lennox. Pp. 305. £12·00. Churchill Livingstone: Edinburgh. 1984.

It is indeed timely that the Clinical Application of Monoclonal Antibodies has been printed in the same year that the Nobel Prize for Medicine was awarded to Drs Milstein and Kohler. Their technique of fusing single antibody producing spleen cells from immunised rodents with myeloma cells capable of secreting antibodies and growing continuously in culture, has made available unlimited quantities of monoclonal antibodies (MoAbs) of exquisite specificity. This publication describes the application of some of these antibodies to a variety of different clinical fields.

Monoclonal antibodies of human origin have obvious advantages over those of rodents in their application as systemic therapeutic agents. The technical problems that still bedevil the switch to the production of human hybridomas are outlined in the opening chapter by $\mathrm{Dr} \mathrm{K}$ Sikora.

Another disappointment in the study of monoclonal antibodies has been the failure in the search for HLA typing reagents as described by Julia and Walter Bodmer. The MoAbs that have been produced reacted mainly with the framework structures of class I or II molecules irrespective of their allospecificity. Although this 'monomorphic' property aided the elucidation of the protein and genomic structure of the HLA genes and their products, allospecific reagents have not become available for general use in tissue typing laboratories.

However, this publication concentrates on the advances in the clinical application of MoAbs, and I have briefly outlined below the areas covered by the various expert contributors.

Dr P Beverly describes the use of monoclonal antibodies for the analysis of $\mathrm{T}$ cell products that have a regulatory role in the immune system.

The combination of MoAbs and fluorescent activated cell sorter has enabled Dr Greaves and his colleagues to identify, isolate, and characterise a variety of rare cells in the early haemopoietic cell differentiation stage in leukaemias.
Dr Jannossy illustrated the use of MoAbs to reduce the graft-versus-host reaction in recipients of bone marrow transplants by the use of a cocktail of anti $\mathrm{T}$ cell reagents.

Drs Dongworth and McMichael have used monoclonal antibodies to inhibit in-vitro functional assays with virus infected cells that correspond to in-vivo immune mechanisms.

Dr P Stern describes the application of MoAbs to cell surface antigen expression on human teratoma cells. It is in the application of MoAbs to tumour immunology that cancer therapy may be advanced. In this respect chapters on the application of passive immunisation of MoAbs in cancer therapy (Dillman and Royston) and tumour imaging and targetry (Sikora and colleagues) are particularly exciting.

The uses of MoAbs in parasite (S Cohen), viral and bacterial (Porterfield and Talin) infection, and neural antigens (J Becker) are also described.

Finally, of specific rheumatological interest Isenberg and his colleagues use MoAbs to understand and dissect autoimmunity in systemic lupus erythematosus, myasthenia gravis, and Graves' disease.

J SACHS

Manual of Fracture Bracing. By A J Hall and R W Stenner. Pp. 61. £16.50. Churchill Livingstone: Edinburgh. 1985.

The manual of fracture bracing is a delightful little book. It contains a very brief and readable review of the conservative treatment of fractures culminating in bracing, and it then goes on in quite adequate detail to discuss the materials and the methods used in the most common fracture sites, namely tibia, femur, forearm, and humerus.

Any book on such a subject by two authors will of necessity be slightly idiosyncratic, but this detracts not at all from the efficacy of what they propound.

I find the description of the techniques very clear, and I have no doubt that this book should be to hand for the orthotist or plaster technician involved in day to day fracture bracing. 